\title{
'Ideias em movimento': José Augusto Garcez e a reinvenção do folclore no Museu Sergipano de Arte e Tradição (1948)
}

\section{'Ideas in motion': José Augusto Garcez and the reinvention of folklore in the Museu Sergipano de Arte e Tradição (1948)}

\author{
Clovis Carvalho Britto' (1) Jean Costa Souzall \\ Universidade de Brasília. Brasília, Distrito Federal, Brasil \\ "Universidade Federal de Sergipe. São Cristóvão, Sergipe, Brasil
}

\begin{abstract}
Resumo: Este artigo analisa a trajetória do colecionador sergipano José Augusto Garcez (1918-1992) e seus trânsitos na reinvenção do folclore, por meio de exposições museológicas, com destaque para a criação do Museu Sergipano de Arte e Tradição (1948), em Aracaju, Sergipe. O interesse é compreender as transformações do folclore, especialmente em Sergipe, por meio da análise da constituição de um campo de produção simbólico, dos trânsitos intelectuais e das estratégias dos agentes responsáveis pela mobilização da crença em determinadas invenções do 'popular', traduzidas em exposições museológicas. Sustentado no referencial teórico-metodológico de Pierre Bourdieu e na análise de um conjunto de fontes inéditas, o artigo contribui para a visualização das táticas utilizadas para a criação de museus dedicados ao folclore no Nordeste do país, no início do século XX, e do modo como esses espaços auxiliaram na mobilização e na consolidação de determinados projetos intelectuais.
\end{abstract}

Palavras-chave: Museu. Folclore. José Augusto Garcez. Sergipe.

\begin{abstract}
This paper analyzes the trajectory of the Sergipean collector José Augusto Garcez (1918-1992) and his transits in the reinvention of folklore through museological exhibitions, with special emphasis on the creation of the Museu Sergipano de Arte e Tradição (1948), in Aracaju, Sergipe. The objective is to understand the transformations of folklore, especially in Sergipe, through analyzing the makeup of a field of symbolic production as well as the intellectual transits and strategies of the agents responsible for mobilizing belief in certain inventions of the "popular" translated into museological exhibitions. Based on the theoretical-methodological reference of Pierre Bourdieu and analysis of a set of unpublished sources, this research contributes to the visualization of the tactics used to create museums dedicated to folklore in the northeast of the country in the early twentieth century, and how these spaces contributed to the mobilization and consolidation of certain intellectual projects.
\end{abstract}

Keywords: Museum. Folklore. José Augusto Garcez. Sergipe.

BRITTO, Clovis Carvalho; SOUZA, Jean Costa. 'Ideias em movimento': José Augusto Garcez e a reinvenção do folclore no Museu Sergipano de Arte e Tradição (1948). Boletim do Museu Paraense Emílio Goeldi. Ciências Humanas, Belém, v. 14, n. 3, p. 1003-1024, set.-dez. 2019. DOI: http://dx.doi.org/10.1590/1981.81222019000300016.

Autor para correspondência: Clovis Carvalho Britto. Universidade de Brasília. Faculdade de Ciência da Informação. Campus Darcy Ribeiro. Brasilia, DF, Brasil. CEP 70910-900 (clovisbritto@unb.br).

Recebido em 08/01/2019

Aprovado em 13/03/2019
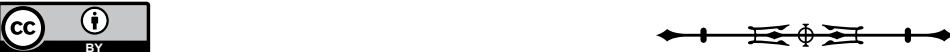
Falar de José Augusto Garcez como personagem que atuou em diferentes campos, homem das letras, colecionador, criador de um museu, mobilizando a partir de suas ações, práticas relacionais em diferentes espaços, é narrar a sua trajetória enquanto agente socialmente instituído, problematizando aquilo que Bourdieu (2007) denominou como 'ilusão biográfica'. Sem dúvida, o caráter autobiográfico presente em diversas obras, mas especificamente em seu livro "Folclore: realidade e destino dos museus" (Garcez, 1958), constitui-se, "[...] pelo menos em parte, na preocupação de dar sentido, tornar razoável, de extrair uma lógica ao mesmo tempo retrospectiva e prospectiva" (Bourdieu, 2007, p. 184), na disputa pelo monopólio de legitimidade dentro dos espaços possíveis. Assim, partindo do nome próprio como objeto de análise, podemos perceber as sucessivas movimentações que José Augusto Garcez mobilizou enquanto produtor e produto de uma construção social, uma vez que, frente à classificação de objetos coletados e preservados em seu empreendimento cultural, o Museu Sergipano de Arte e Tradição contribuiu para a fabricação de tradições da cultura local.

A vida social é composta por objetos que circundam os agentes, proporcionando significados distintos, temporalidades, trajetórias individuais ou coletivas que reverberam em suas práticas culturais cotidianas, a partir “[...] das categorias culturais ou sistemas classificatórios dentro dos quais situamos, separamos, dividimos e hierarquizamos" (Gonçalves, 2007, p. 14). São suportes de memórias que, uma vez acionados, revelam subjetividades perante os embaraços de um macrocircuito de classificações, que, dependendo do seu contexto sociocultural, carregam diferentes marcas do pensamento de determinada época.

No final do século $X I X$ e início do século $X X$, muitos destes objetos, segundo Gonçalves (2007), foram classificados como etnográficos. Logo, corroborando o autor, ao sinalizar que nem toda coleção demarcada como etnográfica "[...] era desenvolvida por antropólogos profissionais, mas por viajantes e missionários" (Gonçalves, 2007, p. 16) e, ainda mais, que muitas dessas coleções não eram frutos de análises epistemológicas sobre entendimento do 'outro', destacamos as ações desenvolvidas pelo sergipano José Augusto Garcez e o seu Museu Sergipano de Arte e Tradição. Não sendo um antropólogo de formação, fez-se viajante, um estudioso das coisas de Sergipe, registrando e preservando objetos que falariam a 'alma dessa gente' aos 'pensadores do nosso povo'. Assim, acreditamos que os museus e as suas coleções são espaços privilegiados para a fabricação de práticas, discursos e crenças que dinamizam a memória e o esquecimento, tornando-se um dos recursos utilizados para a construção de determinadas leituras sobre a identidade nacional e local.

No Brasil, no início do século $X X$, é possível mapear discussões acerca da valorização de elementos que representariam o universo 'popular' brasileiro, como instrumentos de construção e de consolidação de uma possível imagem de nação. A partir da década de 1930, o país viveu algumas iniciativas políticas e culturais que demandaram, para além de outras realizações, ações de preservação de bens que encenariam - a partir de diversos campos, museus, literatura, artes plásticas etc. uma possível imagem de Brasil. Segundo Antônio Albino Canelas Rubim, essas iniciativas ocorrem quando "As classes médias e o proletariado aparecem na cena política" (Rubim, 2007, p. 14), contribuindo para a atuação de uma emergente burguesia dentro dos espaços políticos culturais.

A institucionalização do patrimônio cultural no Brasil ocorre a partir de 1936, em pleno Estado Novo, com a criação do Serviço do Patrimônio Histórico e Artístico Nacional (SPHAN). Sob a atuação de Rodrigo Melo Franco de Andrade como dirigente do órgão, a partir do Decreto-Lei n ${ }^{25}$, de 1937, iniciou-se a construção de um conjunto de narrativas sobre os bens culturais brasileiros, entendido como patrimônio histórico e artístico nacional. Como assinalado por Rodrigo Melo Franco de Andrade, embasado por uma perspectiva de Mário de Andrade acerca da noção de patrimônio, promove-se o "[...] conjunto de bens móveis e imóveis existentes no país e cuja conservação seja de interesse público, quer por sua

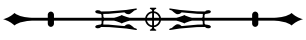


vinculação a fatos memoráveis da história do Brasil, quer por seu excepcional valor arqueológico ou etnográfico, bibliográfico ou artístico" (Andrade, R., 1987, p. 51).

As ações do SPHAN foram marcadas pela identificação e preservação dos bens com referências a uma herança colonizadora, fato que resultou em críticas sobre a representatividade dos bens e que contribuiu para a uma não "[...] interação com as comunidades e públicos interessados nos sítios patrimoniais preservados, [...] [impedindo] o SPHAN de acompanhar os desenvolvimentos contemporâneos na área de patrimônio [...]" (Rubim, 2007, p. 17-18). Este pensamento foi reforçado por Maria Cecília Londres Fonseca, quando analisou a política federal de preservação ao patrimônio cultural e sublinhou uma composição do patrimônio "[...] limitada a uma vertente formadora da nacionalidade, a luso-brasileira, [elegendo] determinados períodos históricos, elitista na seleção e no trato dos bens culturais" (Fonseca, 2009, p. 143).

Em meio a essas tensões, torna-se importante destacar a atuação das Campanhas de Defesa do Folclore Brasileiro que, paralelamente às iniciativas institucionalizadas pelo SPHAN no tocante à busca pela preservação das manifestações culturais e da identidade nacional, estimulou o surgimento de uma rede de intelectuais folcloristas. Essa rede de intelectuais pensava suas representações culturais a partir de uma determinada esfera social - 'o povo' -, que, segundo o antropólogo Vilhena (1997), é denominada de movimento folclorista.

A mobilização dos folcloristas, em 1947, fez surgir a Comissão Nacional de Folclore, que resultou na Campanha de Defesa do Folclore Brasileiro. Os pesquisadores dessa temática passaram a tratar o conceito de folclore como equivalente ao de cultura popular. Desse modo, as ações desses estudiosos foram orientadas na tentativa de transformar o folclore em uma disciplina científica autônoma, com campo de investigação e métodos próprios, uma vez que seus trabalhos, até então, se restringiam a um caráter descritivo dos registros coletados:
De 1947 aos dias atuais, outros capítulos dessa história foram escritos. Constituíram-se coleções públicas e privadas, realizaram-se exposições, foram editados livros, filmes e vídeos voltados para a análise e divulgação das expressões de uma arte oriunda de indivíduos pertencentes às camadas populares ou resultante da ação de comunidades organizadas em torno da produção de objetos da cultura material. Nesse período observa-se também a criação de instituições museológicas nos país, cuja finalidade precípua inclui a coleta, a guarda e a exposição de objetos de origem popular. Tais instituições surgem no contexto de implantação de mecanismos de proteção ao folclore nacional, a partir da iniciativa de uma rede organizada de intelectuais convencionalmente nomeada Movimento Folclórico Brasileiro. (Lima; Ferreira, 1999, p. 102).

Em 1951, durante o I Congresso Brasileiro de Folclore, ocorrido no Rio de Janeiro, os folcloristas promoveram debates acerca das características do folclore e redigiram um documento, a "Carta do Folclore Brasileiro", como forma de estabelecer as diretrizes que reconheciam o estudo deste objeto como parte integrante de outras áreas do saber, como a antropologia cultural e o seu "[...] estudo da vida popular em sua plenitude quer no aspecto material, quer no espiritual, [...] as maneiras de pensar, sentir e agir de um povo, preservadas pela tradição popular" (Carta..., 1952-1955). Portanto, é importante salientar que, segundo Elisabeth Travassos, o movimento folclorista, nesse momento, distancia-se das posições clássicas quanto à noção de antiguidade e oralidade, que impregnava os estudos folcloristas no início do século XIX. Para a autora, "Sob a égide dos relatos de fundação do Brasil a partir dos três povos formadores, o tema privilegiado pelos estudos do folclore passou da poesia popular à música, e em seguida aos 'folguedos'" (Travassos, 1998, p. 187).

Durante essa Campanha, inúmeras instituições especializadas em folclore, a exemplo de museus e órgãos do governo estadual e federal, fizeram-se presentes como espaço político legitimador. A identificação de artefatos classificados como 'folclore', 'cultura popular', 'arte popular', começa a emergir dentro dos cenários museológicos como forma de materializar um discurso que encenaria a 'cultura do povo', ou seja, buscava-se

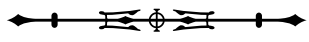


aqueles que estavam à margem da sociedade, com seus costumes, hábitos e criações artísticas sendo classificados como elementos autênticos de uma brasilidade.

No Brasil, a representação da nacionalidade em museus é investigada, por exemplo, tomando-se como referência os intelectuais Gustavo Barroso, Gilberto Freyre e Darcy Ribeiro, conforme o trabalho de Chagas (2009), e suas relações com a criação do Museu Histórico Nacional, do Museu do Homem do Nordeste e do Museu do Índio, respectivamente. A partir das problematizações em torno da identificação dessas instituições, bem como da abordagem que o autor fez acerca do nacional nos museus brasileiros, fica evidente que o tratamento dado a essas coleções traduz uma representação (de) sobre o outro, um olhar a partir de seu ponto de vista cultural. Obviamente, o papel dos museus como suportes na narrativa sobre a nação remonta ao século XIX, em uma perspectiva marcadamente científica, a exemplo da configuração do Museu Nacional, do Museu Paranaense, do Museu Paraense Emílio Goeldi e do Museu Paulista (Schwarcz, 1993; Lopes, 1997).

Atrelados a uma ideia de produção artesanal, ao longo do século $X X$, diversos museus identificaram os artefatos em suas exposições por meio de uma narrativa em que o cotidiano do 'homem comum' fosse ali representado. Evidenciavam objetos que, fabricados em localidades longe dos grandes centros de influência cultural, dialogavam com a população rural ou de cidades do interior, tornando-se o assento de uma 'cultura legítima' de 'representação do povo'. Esses artefatos eram feitos de matérias-primas diversas, como couro, palha, lataria, madeira, barro, começando a compor o imaginário acerca de sertão, de Nordeste, formando coleções particulares, fruto da ação de estudiosos que tratavam sobre a 'cultura do povo'. Nesse contexto, no Brasil, começaram a surgir os museus de caráter etnográfico, museus regionais, museus de folclore e museus de arte popular.

Por esse motivo, intitulamos este artigo de "ideias em movimento", nos termos apresentados por Alonso (2002), visando realizar uma leitura sociológica em torno de conjunturas, confluências e debates que envolveram as interconexões entre os intelectuais dos campos dos museus e do folclore em Sergipe. Isso ganha centralidade quando percebemos, em Sergipe, nas primeiras décadas do século $X X$, iniciativas que apresentavam a cultura local como forma de mediar, a partir de artefatos, arquivos bibliográficos, oralidade, noticiários, uma campanha do que seria a cultura de Sergipe. Acreditamos que, a partir do Museu Sergipano de Arte e Tradição, criado pelo colecionador folclorista José Augusto Garcez, em 1948, é possível entender as estratégias de fabricação de um 'folclore sergipano' junto a outros intelectuais e instituições que, integrados a esse projeto, auxiliaram na consolidação do campo museológico em Sergipe.

Nesse período, o estado de Sergipe possuía dois espaços museológicos que respondiam como lugar de preservação e salvaguarda da memória local: o Museu do Instituto Histórico e Geográfico de Sergipe (IHGSE) (hoje, Museu Galdino Bicho, pertencente à mesma instituição), em Aracaju, e o Museu Horácio Hora, em Laranjeiras. Em seu livro autobiográfico "Folclore: realidade e destinos do museu", Garcez (1958) promove uma crítica no tocante à forma como esses espaços desenvolviam suas atividades culturais no cenário museológico sergipano. Para o autor, ocupando duas áreas do prédio do IHGSE, o museu estava dividido em dois espaços, o térreo e o primeiro andar:

As peças existentes no Museu incorporado ao Instituto Histórico e Geográfico de Sergipe abrangem duas áreas, sendo uma sala no térreo e um salão no segundo. A primeira e principal sala está situada no térreo da aludida instalação, estando regularmente com os objetos arrumados não atendendo ainda as regras e princípios técnicos. Partes dos objetos estão colocadas em peças isoladas e inadequadas, raros objetos trazem etiquetas. Não há salas especiais para exposições, necessário serviço de classificação, livros de visitas, jetões para controle de visitantes, exposições temporárias e comemorativas, estatuto, fichário nem catálogo descritivo. [...] Na sala do segundo andar, todo o acervo encontra-se disperso, não existindo etiquetas, arrumação, bem assim, meios propícios de defesa contra o estrago do tempo, tudo que seja de acordo com os princípios técnicos modernos. (Garcez, 1958, p. 38).

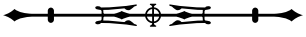

1006 
Desse modo, é possível perceber a preocupação que Garcez tinha quanto aos fazeres técnicos nos museus, ao processo de documentação, preservação, comunicação, exposição, evidenciando que adequar a instituição ao modelo técnico moderno (no tratamento das peças) era pensar uma classificação dos objetos, uma linguagem, uma história a ser narrada a partir de uma reunião de peças em espaços, nesse caso, em salas distintas, formando exposições temáticas, comemorativas. O museu do IHGSE foi fundando em 1917 e, segundo Garcez, era formado por "[...] objetos de variadas espécies sem defesa de valorização" (Garcez, 1958, p. 38).

Outra instituição que existia nesse mesmo contexto era o Museu Horácio Hora, criado pelo Decreto n³1, em 16 maio de 1942, na cidade de Laranjeiras. Segundo Garcez (1958, p. 42), o museu "[...] compreendia apenas uma sala com o acervo espalhado sobre o assoalho e paredes". Não havia "[...] arrumação, organização, peças destinadas a proteção de objetos, etiquetas, inventário nem catálogo descritivo" (Garcez, 1958, p. 42). Esta era uma instituição que, assim como o museu do IHGSE, partilhava de uma prática na qual os fazeres técnicos que visavam à preservação e à comunicação, não correspondia ao que ele considerava como necessários aos fazeres museológicos. Desse modo, através das críticas suscitadas pelo autor, ele se fez um conhecedor da área técnica de museus, um conhecedor da Museologia que, provavelmente, respondia às diretrizes técnicas do Curso de Museus, liderado por Gustavo Barroso, no Museu Histórico Nacional do Rio de Janeiro.

No caso sergipano, é oportuno apresentar alguns antecedentes. Sílvio Romero, crítico, ensaísta, folclorista da cidade de Lagarto, Sergipe, teve sua contribuição na historiografia literária brasileira. Como pesquisador, sob a influência do escritor e jurista Tobias Barreto, também sergipano, dedicou-se em pensar o que seria a 'civilização brasileira'. Em Sergipe, seus estudos, que tinham a temática do folclore, principalmente quanto ao registro de possíveis traços culturais que fundamentariam o 'povo brasileiro', capturados na literatura, na poesia, nos causos etc., embasaram as pesquisas sobre elementos caracterizadores da relação nacional/regional da antiga província. É esse contexto, influenciado pelo pensamento destes autores, que José Augusto Garcez teve como referência para a formulação do seu pensamento enquanto jornalista, colecionador, escritor e poeta:

Em 1947, ainda muito novo, inscreve-se como candidato a poltrona $n^{\circ} 10$, vaga com falecimento de Artur Fortes. Implacavelmente, a inscrição é cancelada pela interferência do acadêmico José Magalhães Carneiro. Inconformado, José Augusto sustenta, no 'diário de Sergipe', uma série de artigos protestando contra a injustiça. E obstinado e idealista, não apaga aspirações nem a inspiração. Ao contrário, toma-se de fúria criativa, escrevendo, agitando os meios culturais sergipanos, liderando intelectuais e fundando movimentos de alta cultura. (Cardoso, 2016, p. 220).

Assim, segundo os aportes sociológicos de Bourdieu (1983a), é possível tomar como objeto de estudo a trajetória de José Augusto Garcez junto ao campo de produção cultural e suas relações enquanto agente socialmente instituído dentro das diversas áreas em que atuou. Reconhecendo as condições sociais do estado de Sergipe no início do século $X X$ e a sua produção cultural no folclore, principalmente na literatura, é possível visualizar a atuação de Garcez, até aquele momento, como jornalista, e as suas estratégias de aquisição de capitais econômicos e culturais, norteando uma nova visão do que seria o folclore em Sergipe e sua prática colecionista.

Dessa forma, evidenciar, a partir da estrutura do campo em jogo - nesse caso, do folclore em Sergipe -, as estratégias de José Augusto Garcez enquanto produtor, contribui para problematizar em que medida o intelectual manipula as regras do jogo e, por meio de estratégias, tenta implantar uma nova estrutura para a produção da crença em si a partir dos empreendimentos realizados, visando à obtenção de legitimidade dentro desse espaço de produção simbólico. 
Segundo Bourdieu (1983a, p. 212), a obtenção de uma autonomia legítima dentro de um espaço de poder é "[...] uma autonomia relativa que se constrói pouco a pouco sob certas condições, no decorrer da história". É notável observar a posição que Garcez ocupava enquanto agente produtor e produto de uma agência nos seus diferenciados campos, e pensar em que medida a crença fabricada no campo dos museus é fruto das relações por eles estabelecidas. Desse modo, é possível situar a trajetória de José Augusto Garcez como metonímia do campo cultural e museológico sergipano ao longo do século $X X$. Homem que, desde cedo, esteve mergulhado nas letras, jornalista e escritor, atuou em diversos periódicos dentro e fora do estado de Sergipe, tendo suas produções registradas nos principais jornais do Rio de Janeiro, de São Paulo e de Alagoas. Dito isso, é notório que José Augusto Garcez soube, a partir de sua posição social, manipular bem seus capitais para determinadas leituras a respeito do que entendia como tradição, arte e cultura no estado de Sergipe.

Em 1953, Garcez criou o Movimento Cultural de Sergipe, a fim de mobilizar uma rede de intelectuais em virtude dos possíveis silêncios no tocante à produção literária neste estado. $\bigcirc$ empreendimento cultural destinava-se a editar obras de intelectuais anônimos, romancistas e poetas sergipanos que não tinham condições de financiar a edição de suas produções. Conhecido por muitos como um mecenas das letras, José Augusto Garcez, a partir do Movimento Cultural de Sergipe, iniciou um processo de divulgação dos fazeres culturais do estado, trazendo para esse circuito a apresentação de narrativas sobre a cultura local, publicando mais de quarenta obras sobre diversos temas, como Sociologia, Biologia, Ensaios, Crônicas, História, Romance, Poesia, Economia, Finanças e Museologia (a exemplo do livro "Folclore: realidade e destino dos museus", de autoria do próprio Garcez), revelando nomes que mobilizariam o campo cultural sergipano e nacional:
José Augusto Garcez revelou Santos Souza, Eunaldo Costa. Publicou, ainda, livros de Florentino Meneses ("Grandeza e decadência e renovação da vida"), José Calazans ("Euclides da Cunha e Siqueira de Menezes"), Orlando Dantas ("Análises da inflação no Brasil"). No gênero Poesia, faz vir à luz, de Santos Souza: "Cidade subterrânea", "Relíquias", "Ode órfica" e "Cadernos de elegias", "Pássaro de pedra e sono"; de José Amado Nascimento: "Sermões", "Minha cidade", "Rapsódia de Aracaju"; de José Sampaio: "Nós acendemos as nossas estrelas". Obras completas de José Maria Fontes, "Sonho e realidade". Publicou mais outros poetas: Jacinto de Figueiredo ("Motivos de Aracaju"), Sindulfo Barreto Filho ("Lagoa do Abaeté"), Giselda Morais ("Rosa do tempo") e outros, inclusive livros de versos do próprio José Augusto Garcez: "Invasão das estrelas", "Mensagens", "Desejo-morto", "Canudos submerso", "Aurora de sangue" e outros. (Cardoso, 2016, p. 220).

É com a publicação destas obras que José Augusto Garcez começa a ter notoriedade dentro e fora de Sergipe, trocando diversas correspondências com escritores, jornalistas, folcloristas e expoentes modernistas, como Carlos Drummond de Andrade e Manuel Bandeira, participando de diversos jornais em Sergipe, Rio de Janeiro, São Paulo, Bahia, e em outros países, como México e Portugal.

Ao analisar esses documentos, é possível atestar os trânsitos culturais que Garcez instituía e o modo como eles reverberaram na formação de seu pensamento, no tocante à preservação e ao registro da cultura local. Sob o apoio do governo de Leandro Maciel, é dado ao "[...] intelectual sergipano, idealizador do Movimento Cultural de Sergipe [...], excursionar as diversas capitais brasileiras, em missão de intercâmbio cultural [...]", sendo recomendado "[...] às autoridades e aos intelectuais patrícios" (Garcez, 1958, p. 156). Dentro dessa perspectiva, o Movimento Cultural promovia, além das publicações, a realização de saraus em livrarias da capital, realizava exposições como "[...] a seção de antropologia cultural, exposição interna e na Livraria Regina Limitada [...] há dez anos, através de PRJ-6, o programa radiofônico Panorama Cultural, no qual havia uma seção sobre a Missão do Museu" (Garcez, 1958, p. 35).

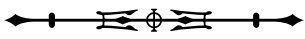


Para além de todo o acervo bibliográfico divulgado por Garcez como editor ou, algumas vezes, como autor, ele iniciou uma campanha em favor da criação de um museu para o estado de Sergipe, em 1948. Publicando em vários jornais, como Diário de Sergipe, O Nordeste, Correio de Aracaju, Sergipe Jornal, todos de Aracaju, Sergipe; A Tarde, de Salvador, Bahia; Diário Carioca, do Rio de Janeiro, Rio de Janeiro; A Gazeta, de São Paulo, São Paulo; observam-se matérias em que destacava a carência, no estado de Sergipe, de um museu que preservasse a memória do 'seu povo'.

O Museu Sergipano de Arte e Tradição foi criado em sua própria residência, na cidade de Aracaju, e se constituiu a partir de sua coleção particular. Devido à constante exportação de obras identificadas como históricas, segundo Garcez (1958, p. 24): “[...] levando em consideração a gravidade que assumia o descaso dos administradores $[\ldots .$.$] , julguei conveniente a começar, em$ 1946, adquirindo com recursos próprios, o acervo que hoje mantenho". Nesses termos, é possível pensar em que medida essa coleção particular, localizada na residência da família, em comunhão com os objetos utilitários da casa, também não contribuiu para que outros agentes também desempenhassem essa atuação colecionista. $\bigcirc$ jornal A Noite, no ano de 1953, destacou, por exemplo: "[...] outro setor do museu sergipano vendo-se o casal José Augusto Garcez e D. Isaura Garcez. Eles cuidam do M. S. A. T. com um verdadeiro carinhos de pais" (Souza, 1953, p. 29). Desse modo, é possível problematizar em que medida a sua esposa, ocupando esse espaço do privado, também era responsável pela configuração das exposições, pela conservação das peças, pela produção de fichas catalográficas ou até mesmo pela seleção de objetos a serem comunicados, até porque, como já foi salientado, esse não era o único projeto cultural partilhado por José Augusto Garcez. Aqui, é importante notar que o papel da esposa não é trivial. Na lógica de uma coleção constituída por uma figura patriarcal, e ligada ao seu nome, esse patriarcado ajuda a naturalizar a ideia de um museu criado por um 'intelectual' masculino.
Junto a esse museu, Garcez também cria um programa de rádio chamado "Panorama cultural" que, para além das prosas e poesias que eram proferidas semanalmente, também servia para informar aos ouvintes os estudos e os serviços prestados no seu museu particular.

O acervo do Museu Sergipano de Arte e Tradição era composto por objetos de procedência da capital do estado de Sergipe e de seu interior, como a cidade de Itaporanga d'Ajuda, onde o intelectual tinha uma residência e seus familiares ocupavam posições na política local. $\bigcirc$ museu tinha como objetivo salvaguardar não só a cultura material do estado, mas todo e qualquer suporte material que tratasse das questões culturais, políticas e históricas da região. Além do museu, o folclorista criou uma biblioteca, denominada Biblioteca Popular Tobias Barreto, em 1948. Paralelamente, ele também fundou um instituto de pesquisa chamado Serviço de Pesquisa e Documentação Científica, para arquivar e preservar documentos de cunho histórico, fatos e acontecimento da cultura, da política e da geografia local.

Desse modo, é possível que tenha sido um serviço de pesquisa onde a aquisição do acervo documental fosse feita para compor parte da coleção do Museu Sergipano de Arte e Tradição, uma vez que, em cartas sugestivas do escritor Luís da Câmara Cascudo a Garcez, em 1951, o mesmo relata que seria interessante que o museu do estado fosse criado seguindo uma perspectiva folclórica. Cascudo, considerado um dos grandes nomes do folclore brasileiro, sugeriu que Garcez criasse um museu pensando-o como espaço movido pela cultura material, e os demais acervos (arquivístico e documental) fossem destinados a outras instituições do estado, como - Arquivo Público e o Instituto Histórico e Geográfico de Sergipe. Portanto, é possível que a coleta da cultura material dentro do campo do folclore servisse de registro, uma forma de evidenciar, através da matéria, os saberes e fazeres dos integrantes de uma determinada camada social. Para além dos registros documentais sobre crenças e os causos por meio da oralidade, os objetos atestariam um saber artístico que, uma vez preservado,

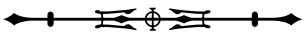


era projetado para o público visitante um ideal de tradição conservado no tempo.

A partir desse estímulo, Garcez iniciou uma campanha visando mobilizar os agentes governamentais, políticos e gestores culturais a favor da criação de um museu para o estado de Sergipe, um espaço onde sua coleção particular fosse abrigada, respondesse às 'normas técnicas' adequadas aos fazeres museológicos e, principalmente, difundisse sua leitura em torno do folclore. Nosso argumento é de que compreender esses trânsitos intelectuais contribuirá para a visualização de algumas das principais referências que orientaram a concepção de folclore em Sergipe ao longo do século $X X$.

\section{JOSÉ AUGUSTO GARCEZ E O MUSEU COMO ESPAÇO EDUCATIVO E SOCIAL}

José Augusto Garcez nasceu em 19 de agosto de 1918, na Usina Escurial (São Cristóvão, Sergipe), filho de Silvio Sobral Garcez e Carolina Sobral Garcez, descendente de uma família possuidora de engenhos. Segundo Santos, S. (2014), Garcez teria iniciado os seus estudos no município de Itaporanga d'Ajuda, tendo aulas com professoras particulares. Seus estudos secundários teriam sido feitos no Colégio Tobias Barreto e concluídos no Colégio Marista, em Salvador, cidade onde iniciou o Curso de Direito que, por problemas de saúde, não concluiu.

De volta ao seu estado natal, publicou em jornais de Sergipe, Bahia e Rio de Janeiro. Em Aracaju, aos dezoito anos, ingressou no jornalismo, estreando com a produção de uma biografia intitulada "Prado Valladares", em 1938. Pesquisador dedicado às áreas de Paleontologia e Antropologia, também escreveu sobre Filosofia do Direito, Prolegômenos, Ciência Zootécnica e Sociologia, tendo uma produção bibliográfica vasta, com destaque para "Folclore: realidade e destino dos museus", "Holandeses em Sergipe", "Destino da província", "Canudos submerso" e "Aurora de sangue". Garcez atuou em diversas instituições culturais dentro e fora do estado, a exemplo do Instituto Histórico e Geográfico de Sergipe e da Sociedade Brasileira de Folclore.
Diante de um possível relato que pudesse indiciar os trânsitos intelectuais que o colecionador e folclorista José Augusto Garcez obteve para construção de suas práticas culturais, é possível sinalizar a presença do folclorista Luís da Câmara Cascudo, a quem recebeu em terras sergipanas no dia 22 de abril de 1951, a convite de Arnaldo Rolemberg Garcez, então governador do estado, primo e cunhado de José Augusto Garcez. Esse encontro foi motivado pela comemoração do centenário da morte do folclorista sergipano Sílvio Romero. Acompanhado por uma comitiva de intelectuais locais, Luís da Câmara Cascudo conheceu os bens naturais em terras sergipanas, os monumentos e os bens culturais do estado de Sergipe, principalmente a antiga capital, a cidade de São Cristóvão.

Certamente, em razão da visita do folclorista potiguar para terras sergipanas e o tamanho do seu prestígio no campo de produção, no dia 20 de abril de 1951 o Sergipe Jornal trazia a matéria "Isto é pra você ler, intelectual de província", assinada por José Cruz. Não obstante sublinhar que o estado possuía um museu com uma vasta coleção de arte popular, artesanato e tudo aquilo que se relacionava ao folclore, considerada pelos doutos como uma das maiores do Brasil, sugeriu a Câmara Cascudo que aproveitasse a sua presença e fundasse, em Aracaju, antes de regressar a Natal, o Centro Sergipano de Tradição:

Somos de parecer que o Centro Sergipano de Tradição deveria ter um Museu em que figurassem os mais diversos pitorescos objetos de indústria empírica indígena, tais como cerâmica, cestos e cestas, côco de tirar água, redes de embalar, redes de pescar, brinquedos (inclusive bruxas de pano e o querido "Mané Gostoso" das crianças do nosso tempo), rendas, colheres de pau, pilões, enfim, tudo que bem demonstrasse aos olhos pesquisadores e curiosos dos visitantes a incipiente indústria popular sergipense. (In: Garcez, 1958, p. 64).

Nesse aspecto, é possível evidenciar os elementos a serem destinados ao museu e a forma como eles seriam classificados. A cultura material indígena é pensada como materialização de um povo que estaria na formação inicial da cultura local, de uma arte 'incipiente', ou seja, de uma

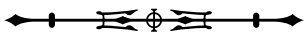


autenticidade étnica tradicional de povo originário daquele lugar. Isso se torna evidente, uma vez que, para Garcez, tudo o que foi assinalado pelo jornalista o mesmo já possuía desde 1948: "[...] o que nos faltava realmente e ainda não existe é um Museu Oficial" (Garcez, 1958, p. 64).

Aberto à sociedade sergipana, o espaço museológico era mediado pelo colecionador que, através do próprio relato, apresentava "[...] a origem do acervo, bem assim o aspecto histórico, empenhando esforço a fim de oferecer ao público o sentido primordial que é de colocar o museu, na missão educativa e social" (Garcez, 1958, p. 35). Para ele, o museu não se configurava mais como um arquivo de peças mortas, para o deleite de turistas, e sim era visto como um espaço de ensino: "[...] salientando aspectos do passado, conjunto de sucessivas e diversas civilizações; [o museu traduziria] a genuína representação folclórica" (Garcez, 1958, p. 23).

Certamente, essas referências foram construídas a partir de suas relações intelectuais, dos debates que travava com outros folcloristas. Garcez dialogava com essas referências estendendo-as para pensar um espaço que preservasse a cultura, a arte e a história do 'povo sergipano' através da cultura material. Talvez esteja aí um dos indícios que promoveram sua inserção no campo museológico e que demarcaram seu pensamento:

No momento contemporâneo, observando-se o desenvolvimento extraordinário das ciências sociais, não se concebe a formação de um museu simplesmente com exposições permanentes de peças representando a pequena vida econômica regional, documentos tradicionais ou não, para a delícia dos espectadores. A cultura material é objeto de exame, estudos e interpretação de base científica. A participação da criação artística do povo, as peças inspiradas e executadas e sem tortura e técnica apuradas, modelos espontâneos, tudo que for preparado por mãos ásperas através de rústicos processos, - são obras intuitivas, simples e esclarecedoras. Permanecem ligados à educação popular. (Garcez, 1958, p. 81).

O intuito era construir um museu que representasse as 'tradições' e que também guardasse documentos vivos do 'patrimônio histórico'. Dando continuidade à campanha denominada por ele de histórico-cultural, visando à criação de um museu para Sergipe, Garcez, em 23 de março de 1958, expediu correspondências ao governador Leandro Maciel Maynard e ao $3^{\circ}$ Bispo de Aracaju, D. José Vicente Távora, a respeito da possível aquisição, em forma de permuta ao estado, do prédio da antiga cúria diocesana, "[...] mansão memorável, onde várias gerações iriam encontrar, através dos documentos vivos, capítulos mais empolgantes da nossa história" (Garcez, 1958, p. 57).

Nessas duas correspondências, Garcez evidencia que, desde 1946, ano em que começou a colecionar 'coisas de Sergipe', foram inúmeras tentativas em prol do incentivo das autoridades locais para aquisição de um espaço físico para o museu de Sergipe, onde salvaguardasse "[...] o patrimônio histórico e cultural do estado" (Garcez, 1958, p. 24). Em análise das correspondências, o que chama atenção são as táticas que Garcez utilizou para a obtenção dos resultados. Mediante à frustação de não ter conseguido realizar isso com o apoio do antigo governador, solicitou ao então governador Leandro Maciel a formação do museu na antiga casa da cúria diocesana, na justificativa de que, em virtude dos trabalhos que o mesmo desenvolvia no estado, "[...] tornar-se-ia imprescindível a criação de mais uma obra na profícua gestão [...], teríamos assim com a soma das peças existentes na biblioteca pública, Instituto Histórico e o Museu Sergipano de Arte e Tradição um acervo completo, plasmado, atuante e instrutivo" (Garcez, 1958, p. 71). Logo, vale destacar que, alegando a não valorização e o estímulo do então governador para a criação do museu, iria encaixotar todo o seu acervo, que estava disponível em um prédio alugado, em sua residência "[...] de limites exíguos, inadaptados às verdadeiras condições museológicas, aonde centenas de peças se amontoam e se espraiam em várias dependências, afetando, inclusive, a saúde de minha família" (Garcez, 1958, p. 71).

O museu serviria para instruir e nortear um entendimento de arte, de valores artísticos, mesmo às

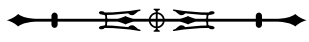


pessoas não habituadas a vivenciar espaços culturais. Como assinalado, espaços sediados pelas elites iriam incorporar outra parte da população, ensinando ao público conteúdos artísticos:

A arte popular - primitiva e a atual - são manifestações de ordem estética cujos elementos transmitem, no tempo e no espaço, vocações que nos levam a compreensão dos espécimes artísticos. Nos ciclos e temas da ciência folclórica, observamos associados às ciências do Homem. Tudo que se coligiu, coordenou e estudou através das classificações científicas tem de figurar explicitamente sem adulterações nas interpretações realizadas. As criações anônimas, as lendas, canções - remotos mistérios das superstições, adagiário e advinhas, danças etc., literatura oral -, ao lado das artes populares, são demonstrações folclóricas ligadas às tradições dos povos e que se vão ampliando nos museus. (Garcez, 1958, p. 95).

Nesse contexto, Garcez evidencia a arte sacra e o papel da Igreja Católica junto à formação do museu:

A igreja terá oportunidade de demonstrar decisiva colaboração na sala destinada a Arte Sacra, representada por peças místicas modeladas no barro e esculpidas em madeira, integradas no departamento de Arte e Cultura, servindo para proteger e conservar as relíquias que se estenderão às peças barrocas, excedentes das restaurações dos Templos antigos e que me coube o cuidado de recolher, preservando dos atentados, forjada pela expressão artística dos abnegados jesuítas, que, inegavelmente, deixam em plagas sergipanas autênticos monumentos estéticos, até então desafiando a ação deteriorante do século. (Garcez, 1958, p. 74).

Como justificativa ao apoio solicitado ao represente da Igreja, Garcez (1958, p. 74) declara: "[...] o sentido social e moral da Arte, sua função na mensagem educativa, bem assim reintegraremos, na devida posição, os benfeitores das civilizações que conceberam trabalhos imperecíveis".

Devido à falta de apoio, é possível que, diante de inúmeras campanhas presentes em diferentes meios culturais, Garcez (1958) tenha dado ao livro "Folclore: realidade e destino dos museus" uma feição autobiográfica, preenchendo-o de posições práticas sobre as atividades desenvolvidas no Museu Sergipano de Arte e Tradição, como também as possíveis reivindicações e sugestões, no tocante à gestão de poderes públicos locais quanto à área cultural e aos órgãos regulamentadores de museus.

Movido por visão modernista, onde era preciso salvaguardar as tradições do passado como elemento de identidade da nação, o registro de elementos da cultura local permeava as ações do folclorista sergipano. Influenciado por uma construção do folclore, amparado no Movimento Folclorista nas décadas de 1950 e 1960, o museu serviria como lugar para a 'educação do povo'. Seria uma forma de vivenciar, através da materialidade, o passado, as tradições, para refletir sobre a cultura local, o 'povo sergipano', através dos objetos em suas temporalidades constitutivas:

\begin{abstract}
O museu, centro de energias culturais e educativas, acolhe os estudantes e lhes transmite a compreensão real de tudo aquilo que os estudos teóricos e metodológicos não conseguiram transmitir com clareza e perfeita visão dos conhecimentos essenciais. Este é um dos aspectos salientes da missão do museu que os museólogos procuram debater no interesse de elucidar, colaborando no âmbito dos problemas educacionais. $\bigcirc$ museu é complemento da experiência cientííca, laboratório da civilização técnica e fundamental dos nossos conhecimentos. Proporciona todos os esclarecimentos e preparação educacional da massa proletária, conhecimentos cientíicos do ensino superior, aprimoramento do ensino primário. O museu é, podemos afirmar, o complemento do saber e ponto vital das relações humanas. (Garcez, 1958, p. 92).
\end{abstract}

Nesse aspecto, é possível que o pensamento de Garcez, no tocante ao espaço do museu e aos objetos de folclore, estivesse pautado no pensamento de Gustavo Barroso, visto que, para ele, "[...] o patrimônio histórico ao lado destas legítimas apresentações da alma sergipana, cada espécie situada em sua área especializada, corrobora para o entendimento histórico-cultural" (Garcez, 1958, p. 95). Em suas andanças pelo país, é provável que Garcez tenha recebido influências desse paradigma museológico dominante, no qual a tradição e a arte popular

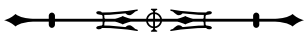


representavam a 'cultura do povo'. Sob esse prisma, Garcez (1958, p. 95) entende que a arte popular, “[...] primitiva e atual, são manifestações e ordem de estética [...]", cuja matéria pode transmitir, nos espaços discursivos, compreensões do desenvolvimento artístico.

A matéria no jornal A Noite, do Rio de Janeiro, datada de 27 de abril de 1957, destaca os trânsitos que Garcez realizava. Sob o título "No Rio, o fundador do Movimento Cultural de Sergipe", o texto informa que Garcez ganhou uma arma das mãos de Gustavo Barroso, como forma de estímulo para as suas ações: "agora mesmo, trouxe do Rio uma arma antiga, que o historiador Gustavo Barroso reputa como única no Brasil, peça raríssima e de inestimável valor" (No Rio..., 1957, p. 6). Esse documento demonstra algumas das parcerias e dos itinerários que o intelectual construiu ao longo de sua trajetória, estímulos prestados pela rede de sociabilidade que o folclorista estabeleceu como resultado de agentes culturais que tinham conhecimentos dos fazeres museológicos.

Nesse caso, Gustavo Barroso, enquanto agente consagrado no campo de produção dos fazeres museológicos no Brasil e na produção de uma narrativa do folclore, ao doar a peça para o museu de José Augusto Garcez, manifesta uma assinatura, ao passo que produz a crença na produção cultural do colecionador. Em diálogo com Bourdieu, no texto "Mas quem criou os criadores?", observa-se que não é a raridade da arma que foi doada a Garcez que importa para a produção da crença, "[...] mas a raridade do produtor, manifestada pela assinatura [...]" (Bourdieu, 1983b, p. 230, grifo do autor), ou seja, é constituída a crença coletiva nesse ato, no qual o poder do produtor manifestado no produto alimenta a crença no museu e, nesse caso, Garcez também se faz a partir desse ato de doação.

Para Garcez (1958), o objeto do folclore faz parte da natureza humana de criar coisas. Independente da área de interesse, este objeto serviria para melhor apresentação das disciplinas instituídas nas escolas, no campo do saber. Era a partir das habilidades técnicas no processo de formação dos objetos que Garcez sustentava a ideia de tradição, objetos populares que possivelmente eram constituídos pelos aprendizados passados de geração a geração, pela oralidade, como assinalava o folclorista Sílvio Romero.

Garcez também foi influenciado pelo pensamento do jurista Tobias Barreto, com referência a uma literatura alemã, onde o tempo e o espaço, a arte e o artista davamse nesses momentos de transferência do saber que, por ser cultural, acontecia de forma dinâmica. $O$ folclorista, na prática, desenvolvia uma cultura local, na qual o objeto do seu museu, a poesia editada pelo Movimento Cultural de Sergipe, a literatura falada na sua rádio difusora Panorama Cultural, constituía o que Bourdieu (1983b) denominou de 'prática distintiva' para obtenção de legitimidade no campo do folclore em Sergipe.

\section{TRÂNSITOS INTELECTUAIS: HERANÇAS DE UM PENSAMENTO FOLCLORISTA}

A seleção de intenções e de gestualidades para a produção de determinadas crenças a partir da manipulação de repertórios expográficos nos museus, compreendidos enquanto espaços de produção, arquivamento e circulação de memórias, dialoga com a expressão 'imaginação museal', cunhada por Chagas (2005), conceito que concebe objetos, formas e imagens como suportes de memórias mobilizados na 'narrativa poética do espaço'. Utilizando esse conceito, Oliveira (2012) apontou indícios de uma 'imaginação museal' no pensamento dos principais estudiosos do folclore nacional, como Sílvio Romero, Mário de Andrade e Gustavo Barroso. Partindo dessas análises, examinaremos em que medida é possível evidenciar uma 'imaginação museal' nas práticas preservacionistas desenvolvidas por José Augusto Garcez.

Em seu livro autobiográfico, Garcez (1958) utiliza, na construção da narrativa, autores que contribuíram para a produção da crença em seu nome e nas ações executadas por ele. Intelectuais que discutem o estudo do folclore enquanto ciência; o campo do museu e sua

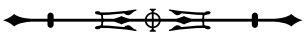


função enquanto espaço dinâmico; a educação a partir dos e nos museus; a cultura material como parte de uma representação folclórica; ou seja, conceitos apreendidos pelo autor que materializaram seus fazeres enquanto poeta, jornalista e folclorista. Na verdade, é importante pensar os trânsitos e as heranças intelectuais que contribuíram para colocar em prática as ações de preservação por meio da 'imaginação museal' dos folcloristas. Para tanto, nos debruçaremos nesses pensamentos que, possivelmente, contribuíram para pôr em prática as ações desenvolvidas por José Augusto Garcez.

No século XIX, a oralidade, os contos, os versos e as lendas talvez sejam os primeiros registros coletados por pesquisadores direcionados em apresentar a produção do 'homem comum' como portador de uma herança que serviria para 'autenticar' uma dada nacionalidade. No Brasil, esses registros direcionados ao popular integraram um processo de valorização do 'povo', dando a este o lugar do primitivismo, de uma cultura pitoresca. Como indica Burke (2010), o 'povo', sendo um termo muito amplo e contraditório, foi definido de várias formas pelos diversos campos do saber.

O folclorista sergipano Sílvio Romero, em meados do século XIX, já desenvolvia pesquisas com o intuito de registrar fatos nacionais/locais. Segundo Vânia Dolores de Oliveira, os seus registros não evidenciavam "[...] propriamente a ideia de museu como entendemos hoje, mas uma nota, um viés preservacionista, percebido na preocupação com o registro das coisas nacionais" (Oliveira, 2011, p. 174). Sílvio Romero, em um momento em que o estudo da cultura ainda não era algo em voga, percebeu, no registro dos contos, da poesia e da música, as particularidades de povos, civilizações e etnias.

Herdeiro intelectual do jurista sergipano Tobias Barreto, que tinha uma produção muito latente no molde de pensar dos germânicos, com as teorias de Kant, Sílvio "[...] chama atenção para coleta de materiais, indicando fontes, nacionalidades e produções recentes originadas dos mestiços e das populações atuais" (Garcez,
1958, p. 133). É nesse contexto de análise e coleta que predominaram os estudos do folclore em Sergipe no século XIX e início do século $X X$. Sob defesa de que o regionalismo é uma constância para a produção do folclore, Garcez, como sergipano e herdeiro desse modelo de apresentação da cultura local, defendia o regionalismo, compreendendo-o como:

[...] testemunhos materiais da arte, nos costumes etc. decorrem da tradição atuante de onde emergem os sentimentos populares. A contribuição rudimentar indígena e africana somada às influências da formação da cultura luso-brasileira são temas pertinentes de interação onde buscamos descobrir os prodígios da criação estética, oral e popular, sobrevivência dos agrupamentos humanos. (Garcez, 1958, p. 132).

Como ora assinalado, surge uma ampliação por parte de Garcez do que seriam esses testemunhos dos costumes, bem como a noção de arte, nesse caso, de arte popular. Assim, é possível supor que os olhares de Mário de Andrade e do historiador Gustavo Barroso tenham influenciado de algum modo Garcez em seus fazeres museológicos no Museu de Arte e Tradição. Para Mário de Andrade, a função dos museus era se tornarem uma instituição "[...] [contrária] à ideia de cemitérios de relíquias, [...] 'museus vivos, que sejam um ensinamento ativo'" (Oliveira, 2011, p. 175), que se assemelha, quanto ao discurso que propagava, à função do Museu Sergipano de Arte e Tradição. Conforme salientou Oliveira (2011), se Mário de Andrade dava maior importância à função educativa da instituição e o seu papel como lugar de conhecimento, mais do que qualquer finalidade outra aos objetos, Garcez partilhava da mesma ideia.

Tendo o modernista criado um anteprojeto que serviu de base para implementação de uma institucionalização do patrimônio e dos museus, Garcez legava a criação de espaços de memória onde seriam fabricadas as representações que formariam o imaginário sobre a nação. Entre as propostas, vale destacar a criação de um Museu de Arqueologia e Etnografia, onde

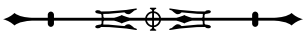


[...] seriam recolhidos e preservados os exemplares representativos da arte popular. [...] [Entendo] as manifestações artísticas, nacional e estrangeira [...] que de alguma forma interessem a Etnografia, "com exceção da ameríndia", enumerando objetos, monumentos - arquitetura popular, cruzeiros, capelas, cruzes mortuárias de beira de estrada, jardim etc., paisagem e folclore - "música popular, contos, história, lendas, superstições, medicina, receitas culinárias, provérbios, ditos, danças dramáticas etc." (Andrade, M., 2002, p. 274 apud Oliveira, 2011, p. 177).

A partir dessa classificação, são notórias as aproximações do pensamento de Garcez no tocante a esse entendimento prévio de arte popular, exceto quanto a não adoção de objetos indígenas dentro desta classificação. Sobre esse viés de arte popular, cunhado pelo colecionador José Augusto Garcez, é possível que o mesmo aderisse expograficamente aos conceitos em torno da etnografia e da arte popular enquanto parte de um folclore constituinte, que, na expografia do seu museu, podem ser percebidos como sinônimos.

Dando continuidade à construção da 'imaginação museal' de Garcez, é notória a influência que o advogado e historiador Gustavo Barroso deteve nos seus fazeres práticos e discursivos de nação, de arte e de popular. É possível dizer que, mergulhado em uma literatura que versa sobre os estudos de patrimônio, nação e memória, Garcez materializou, naquele momento, em Sergipe, uma concepção moderna de museu, construindo uma nova imaginação folclórica e museológica para o estado, diferindo das experiências museológicas até então existentes (Britto et al., 2018).

Como agente consagrado no campo intelectual que versa sobre o estudo de museus no Brasil e a institucionalização da memória nacional, Gustavo Barroso propôs a criação de um museu ergológico brasileiro na década de 1940, projeto que provavelmente influenciou o pensamento de Garcez, principalmente sobre o discurso de que, nas artes populares, estaria a 'alma do povo', a 'nacionalidade brasileira'. Para Oliveira (2012), é interessante se perguntar, no presente, em que medida se torna difícil compreender como Barroso, um homem idealizador de um museu que buscou imortalizar as elites, pode ter olhado para questões do folclore.

Barroso movia severas críticas aos estudos folcloristas que se dedicavam somente às manifestações espirituais, deixando de lado a materialidade de objetos que, pertencentes a esse grupo, poderiam ser preservados, proposta por ele chamada de 'museu ergológico'. Sob esse ponto, é notório como ele contribuiu para a produção dos discursos mobilizados por Garcez em seu livro. Para o sergipano, o folclore defendido enquanto ciência apresentava-se seguindo as propostas de Barroso. De um lado, a anemologia como sinônimo da alma e, de outra parte, a ergologia, debruçada nas artes e ofícios, ilustrando "[...] artes e ofícios tradicionais [...]" do povo brasileiro (Oliveira, 2012, p. 181). Sobre essa classificação do material, é possível deduzir que Garcez teve suas influências na produção de um museu que se assemelhava à proposta de Barroso quanto à ideia de um 'museu ergológico', tendo propagado em seu manifesto para oficializar esse espaço, onde a técnica, "[...] os modos de fazer, que ele denomina, indistintamente, arte [...]" (Oliveira, 2012, p. 181), o que pode ser observado nas quatorze divisões:

\begin{abstract}
Arte da Habitação, Arte Naval, Arte da Pescaria, Arte da Caça, [...] Artes Domésticas (com as subdivisões, culinária, fiação e vestuário e iluminação), Artes do Artesanato, Arte das Representações, Arte Coreográfica, Arte dos Mecanismos, Arte da Destilação, Arte da Feitiçaria, Arte Funerária, Artes da Criação dos Bichos e Artes Diversas. Examinando sua classificação do "material ergológico", vê-se que nas "Artes do Artesanato" Gustavo Barroso incluía: Cutelaria e Armaria, Malharia, Serralharia e Ferraria, Joalharia, Cerâmica, Imaginária, Selaria, Carpintaria, Marcenaria, Sapataria, Funilaria, Cordoaria, Tanoaria, Cestaria e Tecidos de Fibras, Barbearia, Carreiro, Foguetaria. Até mesmo quando enumera os itens que integram a cerâmica, limita-se a seu aspecto utilitário, exceção aberta apenas para as "figuras antropomorfas ou zoomorfas para paliteiro ou brinquedo de criança". (Oliveira, 2012, p. 180-181).
\end{abstract}

Assim, é possível estimar que, entre os agentes que pensaram a formação de um museu popular, das artes populares no Brasil, Gustavo Barroso tenha influenciado

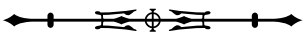


as práticas de coleta que o colecionador sergipano Garcez utilizou, a partir dos anos de 1940, para a formação do seu museu, inaugurado em 1948. Em seu livro, Garcez (1958) cita um pensamento de Barroso, quando, no estudo sobre "Introdução à técnica de museus", afirma que um museu não deve ser "[...] unicamente um necrotério de relíquias históricas, etnográficas, artísticas, folclóricas ou arqueológicas; mas um organismo vivo que se imponha pelo valor educativo, ressuscitando o passado nele acumulado" (In: Garcez, 1958, p. 15).

Sob essa perspectiva, mergulhado nas discussões que reverberam o campo dos museus na década de 1950, e voltando para esse espaço um olhar educativo, aliado a programas institucionais de educação, como lugar fornecedor de cultura, Garcez também se posiciona conforme o museólogo Florisvaldo dos Santos Trigueiro, formado pelo Curso de Museus no Museu Histórico Nacional, quanto ao papel dos museus na educação do povo. Isso se comprova quando Garcez refere-se a um livro de sua autoria, ainda em elaboração, a respeito da "[...] função do Museu no sistema educacional Brasileiro, devidamente ilustrado" (Garcez, 1958, p. 35).

Para Garcez (1958), o espaço do museu caracterizavase como uma 'escola viva', sublinhando o seu papel preponderante na educação do povo e a sua relação com o público. Influenciado pelos estudos do museólogo Florisvaldo dos Santos Trigueiro, entendia "[...] que a finalidade do museu é informar educando [...], atingir os seus fins educativos, os métodos são os mais variados, já que as relações com o público são as mais diversas" (Garcez, 1958, p. 48). Em diálogo com Trigueiro, Garcez construiu uma narrativa histórica de autores por ele referenciados, que o legitimava como herdeiro de um pensamento a respeito desse espaço. Percebe-se que suas ações e motivações manifestam esses pensadores que, refletindo sobre o campo dos museus, do patrimônio, dos estudos do folclore, da cultura material e seu papel como espaço educativo, souberam trilhar caminhos em campos onde tais discussões os reinventavam, ao passo que também fabricavam uma nova narrativa do folclore em Sergipe, a qual valorizava os folguedos enquanto arte, diferindo das propostas de Sílvio Romero e Tobias Barreto.

Todavia, foi a partir do pesquisador, escritor e folclorista Luís da Câmara Cascudo que Garcez sustentou seu pensamento sobre um folclore local/nacional. Considerado um dos maiores pesquisadores do folclore brasileiro, o autor potiguar estudou este assunto como um processo onde a cultura de uma localidade se manifesta a partir de tradições, da preservação de suas raízes culturais, ou seja, uma cultura que é transmitida oralmente e é preservada pelos costumes. É baseado nesse pensamento que José Augusto Garcez empreendeu o seu processo colecionista para mobilizar as 'tradições do povo sergipano'. Em visita ao Museu Sergipano de Arte e Tradição, no ano de 1958, Cascudo registra o arsenal de objetos coletados pelo folclorista sergipano, o que contribui para a compreensão de como se dava o processo criativo do colecionador:

\begin{abstract}
Visito a biblioteca de José Augusto Garcez. E a sua galeria de arte popular. Muitos espécimes curiosos de barro, madeira, osso, pastoris, presépios, o grupo de lampião, macumbas, candomblés, amuletos, reminiscências de viagens. Muita cousa pra ver e estudar. E quadros, fotos, e objetos dignos de demora atenta. A biblioteca anuncia o estudioso que se pode credenciar para todos os voos. Todos os gêneros estão amplamente representados. Documentário sério. A hemeroteca é variada e copiosa. José Augusto Garcez é abelha que ainda não fixou a flor de sua especialização cultural. Sua bibliografia é viva, pessoal, abrangendo os horizontes mais largos e gerais, direito, jornalismo, história, critica poesia, assuntos agrícolas, pecuarismo, etnografia, folclorismo. (In: Garcez, 1958, p. 58).
\end{abstract}

Diante do escrito, é possível perceber que José Augusto Garcez conseguiu compor, para além do museu, um espaço de documentação e preservação do que seria possível e lhe interessava salvaguardar da 'memória do povo de Sergipe'. É notória a participação de Câmara Cascudo diante desse empreendimento cultural, como também se torna uma forma de legitimar suas ações folcloristas, ao mapear esses fazeres culturais no estado.

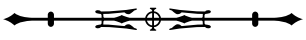


Desse modo, é possível que a formação de uma coleção onde a 'sergipanidade' estava sendo representada evidencie diversas compreensões em torno da ideia de Sergipe. Garcez, como mediador desse fluxo de comunicação, de referências múltiplas, atuando e participando frente a diversas instituições, transportou para sua obra a criação de um Sergipe poético, literário, artístico, histórico e museal, respondendo aos desígnios do campo do folclore da época, com suas crenças, motivações e objetos de estudo. Por isso, a importância de se criar um museu com essas características.

\section{MUSEU SERGIPANO DE ARTE E TRADIÇÃO (1948)}

Localizado na avenida Barão de Maruim, número 629, na capital Aracaju, o Museu Sergipano de Arte e Tradição possuía caráter autônomo e era vinculado à residência de José Augusto Garcez. Denominado como núcleo histórico e artístico na época da sua formação, Garcez criou o museu "[...] em virtude da constante exportação de nossas relíquias históricas" (Garcez, 1958, p. 24). Devido ao descaso quanto à evasão do "[...] patrimônio histórico e artístico cultural do estado" (Garcez, 1958, p. 24), ele iniciou, em 1946, através de recursos próprios, seu ato de colecionar objetos de diversas tipologias e procedências:

A casa de José Augusto Garcez é um museu de pequenas proporções: mas um verdadeiro museu onde se encontram elementos para estudo no setor da história, da pintura, da numismática e principalmente cerâmica. E que paciência para empregar o tempo em preciosas anotações sobre a procedência, a época e a utilidade dos espécimes raros que the enriquecem as paredes, as estantes e os armários. (In: Garcez, 1958, p. 21).

Empreendimento particular, em casa alugada, o museu era amparado pelos conhecimentos técnicos da prática museológica, quanto à organização, arrumação, catalogação, restauração e classificação dos objetos. Garcez classificou a sua coleção da seguinte maneira, ao modo de achados e aquisições:
A - Achados referentes à Paleontologia (fósseis de Mastodonte e Megatherium) e de outros animais.

B - Objetos que representam a etnologia brasileira. Aquisições.

C - Arte Sacra: - imagens em madeira, terracota, porcelana, gesso, cera, bronze. Sinos, peças barrocas etc.

D - Arte popular em geral, inclusive artesanato. Especificação do material: terracota, couro, barro comum, chifres, sisal, osso, cipó, palhinha, taquara, tucum, fio, caroá, coco, flecha etc.

E - Armaria: - pistolas, armas brancas, lanças, trabucos, fuzis, rifles, garruchas e espadas. Máquinas de guerra: - canhões e balas.

F - Instrumento de tortura: - tronco.

G - Ciclo do Cangaceiro: embornais de pano e couro, cantil, chapéu e punhais que pertenceram aos bandidos: José Baiano e Lampião.

H - Ciclo da Escravidão - peças e documentos.

I - Iconografia: imagens e quadros.

J - Animais paquidermizados.

K - Antropologia Cultural. (Garcez, 1958, p. 34).

Diante do que foi enumerado nos itens anteriores e da forma como Garcez classificou a sua coleção em categorias, informada no seu livro "Folclore: realidade e destino dos museus", é possível atestar que a formulação do seu pensamento sobre o folclore se faz a partir dos seus trânsitos entre o campo do folclore, dos museus, do entendimento de arte nesses espaços culturais, bem como da ideia de tradição.

Em nenhum momento José Augusto Garcez defendeu a formação do seu museu enquanto folclore, mas como um museu misto. $O$ pensamento de arte popular aplicado ao museu, em resposta sugestiva às correspondências trocadas por Luís da Câmara Cascudo, seria uma das faces do folclore. Influenciado também pelo pensamento de Gustavo Barroso, quando este promoveu a proposta de um 'museu ergológico', um museu da 'alma popular' para nação, entendeu esses elementos

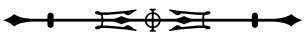


enquadrados na categoria de arte que, frente ao universo popular, estariam mais atrelados às habilidades artísticas que o agente desenvolvia no objeto material, adotando, dentro dessa perspectiva, como instrumento, o manual técnico de museus elaborado por Gustavo Barroso.

Garcez construiu, em Sergipe, o entendimento de um folclore que defendia a oralidade, a poesia e a cultura material, esta última reconhecida como arte. Logo, é notório no colecionador algumas contradições do que ele entende enquanto a funcionalidade do espaço museu e a aplicação do estudo do folclore nesse espaço.

Na prática, no tocante à criação de sua coleção, é possível atestar que o seu museu seja mais um 'gabinete de curiosidades', um lugar de coisas de Sergipe. Todavia, no momento de implantação de um 'museu oficial', institucionalizado, se respaldou dos conceitos técnicos e práticos de classificação, preservação, comunicação, e do conceito de museu formulado pelo International Council of Museums (ICOM), seus objetivos para a sociedade, missão educativa e o papel das escolas dentro desse processo de aprendizagem.

Segundo Cláudio de Jesus Santos, a coleção de Garcez foi fruto das viagens que o colecionador fez pelo interior do estado de Sergipe, baseadas no ideal de preservação do popular, do tradicional. Sob influência do pensamento modernista, o museu surgiu com o "[...] intuito de musealizar a cultura popular sergipana através de sua coleção, a fim de inserir Sergipe nesse projeto de modernidade cultural" (Santos, C., 2014, p. 60).

É possível perceber, nas práticas executadas pelo intelectual, que a informação transmitida a partir da coleção estava muito embasada por uma narrativa histórica, onde os tempos do passado e do presente seriam evidenciados pelas habilidades técnicas, pelos objetos históricos, pelas narrativas míticas que fomentariam a 'tradição do povo sergipano'. A cultura material passaria a ser um atestado dos avanços, do tempo e do espaço que responderia à cultura de Sergipe.

Portanto, é importante analisar, ainda que de forma inicial, as fotografias publicadas no livro autobiográfico do colecionador (Garcez, 1958), para um possível entendimento de como se configurava a expografia do Museu Sergipano de Arte e Tradição e quais representações materiais ele buscou salvaguardar como expressão cultural dos fazeres artísticos do 'povo sergipano'. O estudo das imagens, nesse caso, como fonte de análise, torna-se ferramenta significativa, uma vez que a publicação em uma de suas obras é parte de uma estratégia de promoção e divulgação de suas práticas museológicas, construindo a fabricação da crença em si, a partir do empreendimento criado (Bourdieu, 2002). Após a morte do colecionador, na década de 1990, a coleção do museu foi desmembrada para outras instituições museológicas no estado (Museu Histórico de Sergipe, Museu Afro-Brasileiro de Sergipe e Memorial de Sergipe), encenando, hoje, novas narrativas curatoriais. Na análise desses registros, publicados como imagens ilustrativas de uma prática expográfica na primeira metade do século $X X$, é possível delinear uma narrativa histórica de como se configuravam os fazeres museológicos e folclóricos em Sergipe, a partir do pensamento do colecionador.

Assim, orientado pelos aportes analíticos do historiador Burke (2004), quando sinaliza a importância do uso da imagem como fonte capaz de evidenciar um 'testemunho ocular', percebemos de que forma, através das análises desses registros, é possível evidenciar uma provável prática museográfica que reverberava em Sergipe nas primeiras décadas do século $X X$.

\footnotetext{
"Existentes por toda a Europa, durante os séculos XVI e XVII, coleções de objetos raros ou curiosos receberam o nome de Gabinetes de Curiosidades ou Câmaras de Maravilhas, em alemão Kunst und Wunderkammer. Pomian (1982), no texto "La culture de la Curiosité", conta que existiram centenas, senão milhares, de gabinetes pela Europa, neste período, mantidos por príncipes ou casas reais, humanistas, artistas ou ricos burgueses; elementos representantes da cultura erudita interessada em conhecer e colecionar o mundo que os cercava" (Raffaini, 1993, p. 159).
}

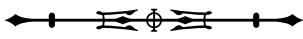


Para Peter Burke, o uso da imagem como testemunho histórico constitui-se em uma importante ferramenta de análise para uma pesquisa científica de caráter históricocultural. Segundo seus apontamentos, a imagem, para além de um mero registro ilustrativo de informações de resultados analíticos já alcançados, pode, de forma criteriosa, tornar-se uma importante fonte de análise de possíveis evidências capazes de alcançar impressões de uma determinada época, de um determinado fazer social, na construção de uma narrativa histórica. Dessa forma, em diálogo com o autor, o registro aqui analisado configura-se em fotografias que podem ser tanto uma evidência histórica quanto a própria história, visto que a sua produção se faz a partir de um olhar de uma determinada escala social, de um interesse a ser atingido por Garcez.

Analisaremos, desse modo, os registros fotográficos que materializam, no presente, um projeto fundado pelo colecionador sergipano em meados do século $X X$. $O$ fato de existirem poucos estudos sobre essa coleção contribui para a percepção de ideias e valores que, para além da materialidade dos objetos expostos e da própria imagem, sublinham possíveis aspectos da mentalidade, das narrativas instituídas pelo folclorista. Para uma melhor apresentação, as imagens aqui divulgadas foram organizadas seguindo as propostas criadas pelo próprio colecionador, quando o mesmo diz, em legenda, que se trata de determinadas coleções.

Na imagem representativa da Seção de Artesanato (Figura 1), é possível perceber expostos o artesanato sergipano, a Bandeira Nacional da República Portuguesa de 1910 e a Bandeira Nacional do Brasil, sugerindo uma formação de painel, um mural, articulador da cultura local/ nacional e da cultura luso-brasileira. É provável que essa foto tenha sido tirada durante a década de 1940, quando a política em prol de uma nacionalidade brasileira se dava a partir das influências dos povos, das diversas culturas. Essa apresentação por meio de navios e caravelas, da cruz de malta, pode remeter a uma narrativa onde o artesanato sergipano é visto pelo olhar do colonizador,

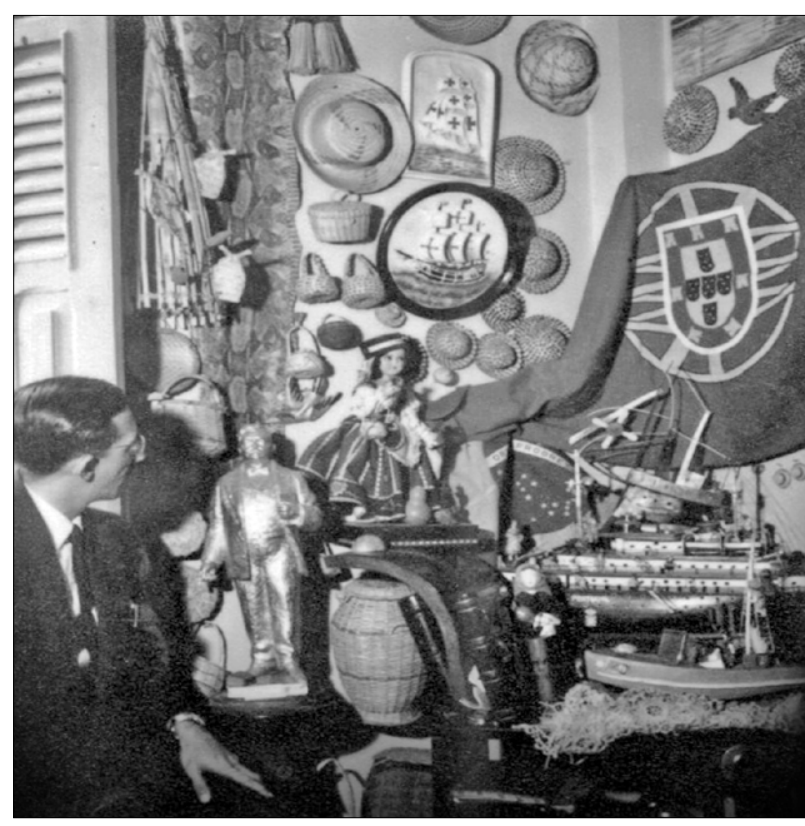

Figura 1. Seção de Artesanato. Museu Sergipano de Arte e Tradição. Fonte: Instituto Tobias Barreto de Educação e Cultura/Universidade Tiradentes (UNIT) (1958).

pelo referencial luso-brasileiro. Garcez, como herdeiro de uma aristocracia, pode ter sido influenciado por um discurso onde a seleção de inúmeros objetos apresenta a cultura sergipana nos seus saberes, tendo o artesanato sergipano, os chapéus de couro e palha, quadros e outros objetos uma visão onde arte e tradição eram traduzidas na ideia do artesanato enquanto elemento de uma referência colonizadora, difundindo o culto ao herói colonizador.

Sendo assim, provavelmente, a realização do museu e a forma de classificação de sua coleção viriam a integrar um discurso de brasilidade construído através da diversidade cultural de cada região, evidenciando as particularidades de cada espaço que legitimariam a nação como um todo. O movimento regionalista, que contou com vários seguidores entre artistas e literatos, desempenhou um papel significativo para a construção dessa brasilidade, permeado por uma narrativa de preservação de fatos e signos, e pela memória de determinados grupos sociais.

Esse pensamento dialoga com o trabalho do historiador Albuquerque Júnior (2013), ao problematizar

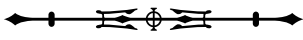


a fabricação do Nordeste. Segundo o autor, o sistema republicano apresenta para as elites políticas e intelectuais o trabalho de refletir sobre o que é do 'povo', bem como dirigir ações e discursos para este. Dessa forma, a percepção do outro se faz presente pela diferença, dando margem ao que viria a ser denominado de 'estudos de folclore ou cultura popular'2.

$\bigcirc$ jornal $\bigcirc$ Tempo, da cidade de São Paulo, em 14 de agosto de 1953, sob título "Cria forças em Aracaju, ressurgimento cultural: novos escritores no estado mirim", noticiava a criação do Museu Sergipano de Arte e Tradição como parte de um ressurgimento cultural da capital. Segundo o jornal, uma das inciativas era a coleção particular ligada ao "nome incansável [de] José Augusto Garcez", realizando uma descrição desse espaço museológico a partir da fala do folclorista Luís da Câmara Cascudo:

Sobre este Museu, transcrevo uma opinião do ilustre escritor Luiz Câmara Cascudo, um grande amigo das coisas de espírito sergipano. $\bigcirc$ museu dará a visão panorâmica do esforço sergipano de acomodação e vitória sobre a terra, instrumento de caça e pesca, cesteira, a arte linda dos oleiros, artefatos de couro, a documentária do ciclo do gado, rendas, enfeites pessoais, decoração dos ambientes coletivos, tudo quanto possa testemunhar em sua simplicidade honesta e clara a vida atual do trabalhador sergipano de ambos os sexos. Não é, visivelmente, uma galeria etnográfica ou de antropologia cultural. Antes positiva aos olhos dos estudiosos como vive e reside, perpetuando-se no tempo o sergipano em todos os seus labores cotidianos e normais. (Cria..., 1953, p. 9).

Entre as inúmeras correspondências trocadas por Garcez com intelectuais de diversas áreas do saber e regiões, chama atenção a correspondência com o folclorista Luís da Câmara Cascudo, quando a este é feita uma observação sugestiva de suas práticas museológicas em Sergipe. Segundo Cascudo, era preciso criar uma "[...] exposição da arte nos seus processos evolutivos, a expressão artística das nossas tradições estruturada e generalizada apenas na ambiência popular: indumentária, arte popular, artesanato, peças do ciclo do couro etc." (In: Garcez, 1958, p. 62-23).

Dessa forma, é possível avaliar que, para o folclorista, era necessário um espaço onde pudesse ser criado um museu de artes representadas nas suas variadas formas, no sentido folclórico. Isso se torna relevante quando, através dos registros fotográficos, evidenciou a exposição das artes populares em ângulos diferentes do mesmo espaço (Figuras 2 e 3). Nas imagens, é possível perceber a notoriedade do universo da pecuária como referência representativa da arte popular sergipana.

Em grande parte da historiografia sergipana, a pecuária adquiriu espaço de legitimidade na economia local, juntamente com a cana-de-açúcar (Leal Diniz, 2013). Lugar de grandes pastos, Sergipe destacou-se na pecuária, fator relevante, visto que é possível perceber o entendimento de arte popular no tocante a objetos representativos do 'povo sergipano', a presença desse universo com imagens de bois em argila destacando-se na exposição, bem como a própria força que a figura do boi tem nas expressões populares, como os reisados, bumba-meu-boi, o próprio couro, o cangaço e o sertão.

Nesse caso, ainda que de forma hipotética, o entendimento de arte popular em Sergipe, através da materialidade exposta, elementos do cangaço na parede, miniaturas de representações de bovinos em argila, uma ossada de boi com chifres, dialoga com uma ideia de arte

\footnotetext{
2 Surgem, nesse momento, diversas disputas entre folcloristas e antropólogos em torno da legitimidade do fato folclórico: "[...] um dos trabalhos mais abrangente relativos à antropologia brasileira é um roteiro bibliográfico elaborado por Melatti (1984), onde podemos encontrar uma referência aos estudos de folclore. Ela aparece em subitem intitulado 'A abordagem funcionalista do folclore', que registra a polêmica provocada pela negativa de Florestan Fernandes em reconhecer nos estudos de folclore uma ciência social, despertando repostas de Edison Carneiro. Ao descrevê-la, os folcloristas anteriores a esses dois autores são caracterizados como produtores de trabalhos, em sua maioria, de mero 'caráter descritivo', que 'quando chegam à interpretação', tenderiam 'a tomar um cunho difusionista'" (Vilhena, 1997, p. 60).
}

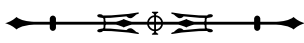




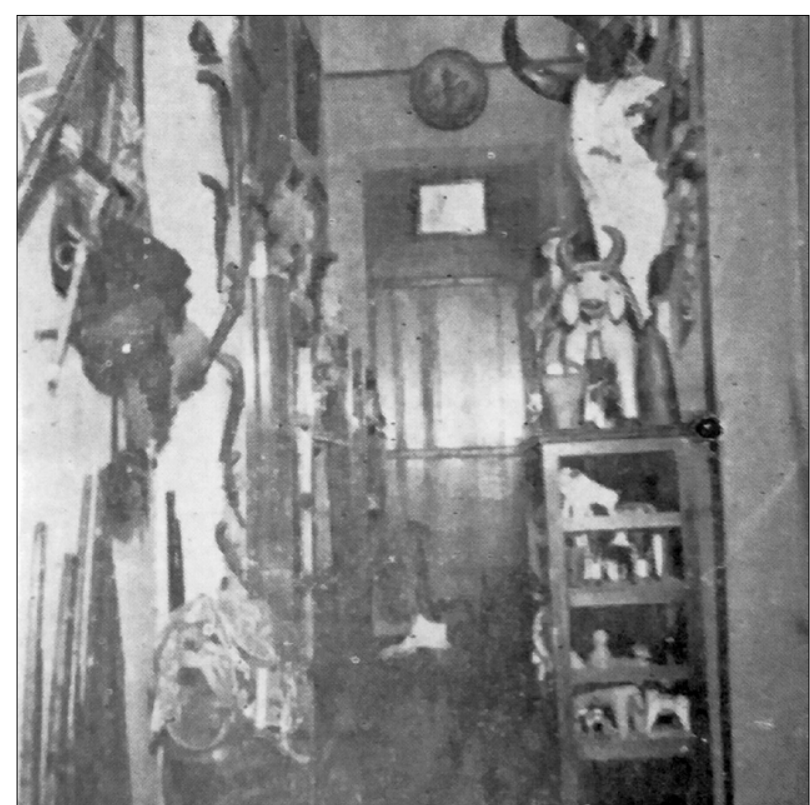

Figura 2. Seção de Arte Popular, Museu Sergipano de Arte e Tradição. Fonte: Garcez (1958, p. 119).

que representa uma cultura sertaneja. Na busca por um olhar voltado para a cultura mais próxima às raízes do 'povo brasileiro', nesse caso o sergipano, o sertanejo, a pecuária ganha centralidade nos discursos de um artesanato deste local.

É possível visualizar a presença de vários elementos culturais que remetem a um paradigma evolucionista, a partir do olhar de alteridade de uma antropologia do século XIX, que representa essa prática etnográfica nos estudos em Sergipe (Figura 3). O museu, nesse caso, seria mais um abrigo de coleções 'exóticas' que, organizadas museograficamente, (re)apresentaria a evolução do 'povo sergipano', a 'sergipanidade' sendo imaginada a partir de uma narrativa onde a referência da antropologia biológica nos museus do século XIX fundamentava esse espaço.

O museu que seu criador apresentava como sendo de vocação educativa, provavelmente tinha sua exposição vinculada a uma grade curricular de estudos primários e/ou secundários com assuntos que versam sobre essa temática. Talvez servisse não de laboratório de pesquisa e de estudos, como os museus de ciências no século XIX, mas

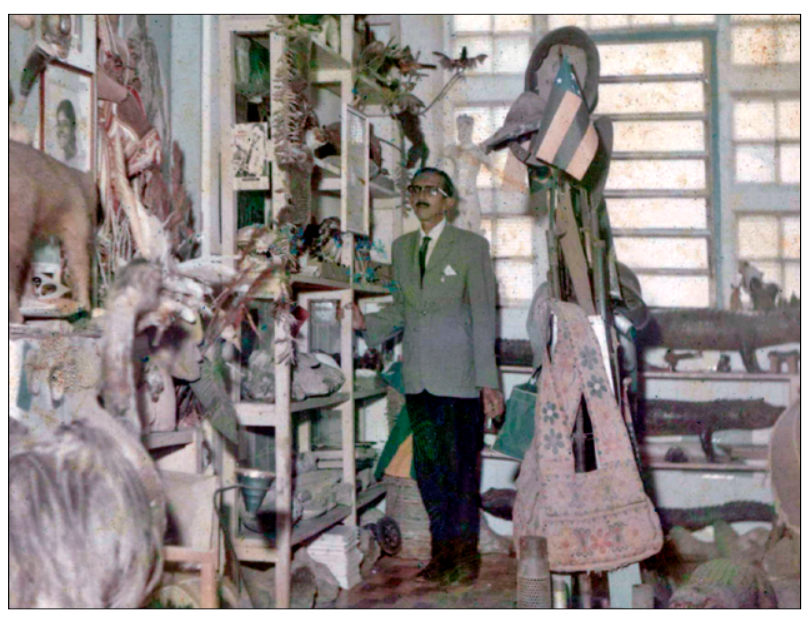

Figura 3. Seção de Antropologia Cultural, Museu Sergipano de Arte e Tradição. Fonte: Instituto Tobias Barreto de Educação e Cultura/ Universidade Tiradentes (UNIT) (1958).

como espaço de informação, onde, através dos objetos e das narrativas atribuídas a estes, complementasse o ensino ministrado em Sergipe, atentando para as possíveis peculiaridades da cultura sergipana.

Os registros publicados pelo próprio Garcez tornamse uma fonte de análise fundamental para perceber como o discurso narrativo, através de arranjos de objetos coletados, preservados, classificados e expostos, apresenta um pensamento de uma época sob determinadas categorias como etnográfica, antropologia cultural, arte popular, artesanato etc. Influenciado por debates científicos que circundavam o estudo do folclore e da antropologia enquanto 'verdadeira' ciência do homem, Garcez defende que o folclore é uma fase inicial de qualquer estudo, com seus métodos e técnicas nas diferentes áreas. Na prática, as classificações de áreas não eram bem evidenciadas na exposição, é possível que o mesmo mediasse a sua coleção sem se preocupar com conceitos científicos, mas a partir de uma narrativa histórica.

As análises desses registros demonstram que a construção das seções expositivas segue uma narrativa contínua, onde a apresentação dos objetos classificados difundia determinadas ideias sobre os fazeres culturais sergipanos. Saberes em diálogo com referências da

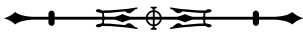


antropologia do século XIX, reforçando o lugar naturalizado do índio, a partir de um olhar exótico, bem como o lugar do negro e as referências de uma 'tradição sergipana', formulada a partir da junção das três raças, proposta construída a partir do pensamento influenciado pelos folcloristas no início do século $X X$. Assim, na qualidade de classificar as referências do 'povo', nesse caso do 'sergipano', de uma 'cultura sergipana' e sua representatividade cultural, é provável que o pensamento defendido por Garcez quanto à formação de sua coleção dialogue com uma prática na qual o uso da categoria popular e suas classificações silenciavam as relações sociais destes. Vale ressaltar que, nesse contexto, o uso das expressões 'povo' e 'popular' está dirigido para camada social desfavorecida, seja no sentido de capital cultural seja no de capital econômico. Portanto, o museu seria um espaço onde essa população homogeneizada teria acesso à cultura, à arte e ao mundo dos museus. Desse modo, o ato colecionista e sua exposição consistem em uma (re)significação dos elementos culturais, que traz artefatos representativos do 'povo' classificados e (re)classificados por uma política de representação. As expressões culturais daqueles que o nomeiam, que o criam, passam a ser registradas como arte popular, resultante de um "[...] deslocamento de sentido, inclusive, de lugar de inscrição para serem vistos e ditos como folclore ou cultura nordestina" (Albuquerque Júnior, 2013, p. 29).

No Museu Sergipano de Arte e Tradição, por meio dos registros imagéticos, e nos textos sobre o modo como as exposições foram montadas, é possível identificar, entre outras coisas, aquilo que Albuquerque Júnior (2013) denominou de 'museu de tudo', lugar onde os fragmentos ilógicos ganham uma coerência, selecionados entre variedade de formas e materiais de expressão de um 'povo', os quais foram e são produzidos e reproduzidos, mediando tempo e espaço de representação da 'tradição do povo sergipano'.

Para Bourdieu, uma das propriedades do campo de produção cultural "[...] reside no fato de os atos que nele se realizam e de produtos que nele se produzem conterem [na] prática (por vezes explícitas) a história do campo" (Bourdieu, 1983b, p. 228). Nesse caso, é possível reconhecer que as práticas executadas por Garcez reverberavam fatos correspondentes à própria história do campo em que estava inserido. Portanto, evidencia a literatura no folclore que Garcez reinventa como literatura falada na rádio difusora, inovando na construção do consumo deste e na invenção de uma coleção classificada na sua materialidade enquanto face representativa de um folclore sergipano. Logo, é possível perceber que, em Sergipe, a história do campo do folclore se dava a partir da literatura, da prosa, dos contos e dos causos. Assim, é possível que na 'imaginação museal' de José Augusto Garcez haja um discurso sobre folclore inédito no estado, no que tange à classificação de objetos atrelados ao conceito de arte e tradição e, principalmente, face ao conceito de arte no singular. Para Garcez, a arte popular era vista como uma subclasse agrupada ao seu entendimento de folclore enquanto ciência. $\bigcirc$ folclore, por meio do estudo de várias disciplinas do saber, materializaria distintas temáticas sobre o estado de Sergipe.

Sob influência dos museus alemães, entendendose como 'museu misto', o Museu Sergipano de Arte e Tradição responde, em seu aglomerado de objetos distintos, a uma ideia de classes e subclasses de estudo do folclore, o que talvez se justifique quando sugere que o museu devia priorizar a arte em seu 'processo evolutivo'. É possível atestar que, no pensamento de Garcez, o folclore se fazia enquanto área que se materializa através da crença nos objetos do homem, as distintas áreas do saber através do processo educativo. Diante desse fato, o folclore, no tocante à sua prática museal, se encaixa como espaço que, através de uma técnica amparada aos moldes modernos, daria conta de perceber a 'evolução' do homem nas diversas práticas da sua história, instituindo um 'museu misto', onde a diversidade das peças, biblioteca, arquivo de pesquisa, editora e rádio difusora movimentavam o campo cultural, atribuindo caráter dinâmico, mostrando o passado

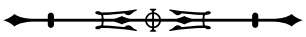


para fabricação ou reinvenção do presente. $O$ saber que pode ser aprendido a partir do objeto dependeria da área de estudo de interesse (história, geografia, arte, arte popular, paleontologia etc.) inserida na exposição; e isso explica a própria mudança de objetos que Garcez manipulava, reinventando sentidos.

\section{REFERÊNCIAS}

ALBUQUERQUE JÚNIOR, Durval Muniz de. A feira dos mitos: a fabricação do folclore e da cultura popular (Nordeste 1920-1950). São Paulo: Intermeios, 2013.

ALONSO, Ângela. Ideias em movimento: a Geração 1870 na crise do Brasil Império. São Paulo: Paz e Terra, 2002.

ANDRADE, Mário de. Anteprojeto para criação do Serviço do Patrimônio Artístico Nacional. Revista do Patrimônio Histórico e Artístico Nacional, Rio de Janeiro, n. 30, p. 271-287, 2002.

ANDRADE, Rodrigo Melo Franco de. Rodrigo e o SPHAN. Rio de Janeiro: Ministério da Cultura, 1987.

BOURDIEU, Pierre. A ilusão biográfica. In: FERREIRA, Marieta de Moraes; AMADO, Janaína (org.). Usos e abusos da história oral. Rio de Janeiro: Editora FGV, 2007.

BOURDIEU, Pierre. A produção da crença: contribuição para uma economia dos bens simbólicos. São Paulo: Zouk, 2002.

BOURDIEU, Pierre. Questões de sociologia. Rio de Janeiro: Marco Zero, 1983a.

BOURDIEU, Pierre. Mas quem criou os "criadores"? In: BOURDIEU, Pierre. Questões de sociologia. Lisboa: Fim de Século, 1983b. p. 217-231.

BRITTO, Clovis Carvalho; DANTAS, Rafael Jesus da Silva; SANTOS JUNIOR, Roberto Fernandes dos. Sob os véus de Mnemosyne: a imaginação museal de Maria Thetis Nunes. Aracaju: Editora da UFS, 2018

BURKE, Peter. Cultura popular na Idade Moderna: Europa, 15001800. São Paulo: Companhia das Letras, 2010.

BURKE, Peter. Testemunha ocular: história e imagem. São Paulo: EDUSC, 2004.

CARDOSO, Marcos. Brava gente sergipana e outros bravos: Manuel Machado - 100 anos. Aracaju: Edise, 2016.

CARTA do Folclore Brasileiro. In: CONGRESSO BRASILEIRO DE FOLCLORE, 1., Rio de Janeiro, 1951. Anais [...]. Rio de Janeiro: Ministério das Relações Exteriores, Serviço de Publicações, $1952-$ 1955. $7 \mathrm{p}$.
CHAGAS, Mário de Souza. A imaginação museal: museu, memória e poder em Gustavo Barroso, Gilberto Freyre e Darcy Ribeiro. Rio de Janeiro: Ministério da Cultura: IBRAM, 2009.

CHAGAS, Mário de Souza. Pesquisa museológica. MAST Colloquia, Rio de Janeiro, v. 7, p. 51-64, 2005.

CRIA forças em Aracaju, ressurgimento cultural: novos escritores no estado mirim. O Tempo, São Paulo, 14 ago. 1953. p. 9.

FONSECA, Maria Cecília Londres. O patrimônio em processo: trajetória da política federal de preservação no Brasil. 3. ed. Rio de Janeiro: Editora UFRJ, 2009.

GARCEZ, José Augusto. Folclore: realidade e destino dos museus. Aracaju: Livraria Regina, 1958.

GONÇALVES, José Reginaldo Santos. Antropologia dos objetos: coleções, museus e patrimônios. Rio de Janeiro: Ministério da Cultura, 2007. (Coleção Museu, Memória e Cidadania).

LEAL DINIZ, Diana Maria de Faro (org.). Textos para a história de Sergipe. 2. ed. São Cristóvão: Editora da UFS; Aracaju: IHGSE, 2013.

LIMA, Ricardo Gomes; FERREIRA, Cláudia Márcia. O Museu do Folclore e as artes populares. Revista do Patrimônio Histórico e Artístico Nacional, Rio de Janeiro, n. 28, p. 101-119, 1999.

LOPES, Maria Margareth. O Brasil descobre a pesquisa científica: os museus e as ciências naturais no século XIX. São Paulo: Hucitec, 1997.

MELATTI, Julio Cezar. A antropologia no Brasil: um roteiro. Revista Brasileira de Informação Bibliográfica em Ciências Sociais, Rio de Janeiro, n. 17, p. 3-52, jan./jun. 1984.

NO RIO, o fundador do Movimento Cultural de Sergipe. A Noite, Rio de Janeiro, 27 abr. 1957. Caderno 1, p. 6.

OLIVEIRA, Vânia Dolores Estevam de. A "Imaginação Museal" dos folcloristas. Textos Escolhidos de Cultura e Arte Populares, Rio de Janeiro, v. 9, n. 2, p. 171-191, nov. 2012.

OLIVEIRA, Vânia Dolores Estevam de. Museu do Folclore Edson Carneiro: poder, resistência e tensões na construção da memória da cultura popular brasileira. 2011. Tese (Doutorado em Memória Social) Universidade Federal do Estado do Rio de Janeiro, Rio de Janeiro, 2011.

POMIAN, Krzysztof. La culture de la curiosité. Le Temps de la Réflexion, Gallimard, Paris, p. 337- 359, nov. 1982.

RAFFAINI, Patricia Tavares. Museu contemporâneo e os Gabinetes de Curiosidades. Revista do Museu de Arqueologia e Etnologia, São Paulo, v. 3, p. 159-164, 1993.

RUBIM, Antônio Albino Canelas. Políticas culturais no Brasil: tristes tradições, enormes desafios. In: RUBIM, Antônio Albino Canelas; BARBALHO, Alexandre (org.). Políticas culturais no Brasil. Salvador: EDUFBA, 2007. p. 11-36. (Coleção Cult).

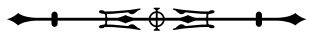


SANTOS, Cláudio de Jesus. Realidade e destino de uma coleção: José Augusto Garcez e sua contribuição para a museologia sergipana. Revista Eletrônica Ventilando Acervos, Florianópolis, v. 2, n. 1, p. 54-63, nov. 2014

SANTOS, Silvaney Silva. $\bigcirc$ mecenato das letras em Sergipe: José Augusto Garcez e o Movimento Cultural de Sergipe (1950-1960). In: CONGRESSO SERGIPANO DE HISTÓRIA, 4.; ENCONTRO ESTADUAL DE HISTÓRIA DA ANPUH/SE, 4., 2014, Aracaju. Anais [...]. Aracaju: Instituto Histórico e Geográfico de Sergipe, 2014. Não paginado. Tema: $O$ cinquentenário do golpe de 64 .

SCHWARCZ, Lilia Moritz. O espetáculo das raças: cientistas, instituições e questão racial no Brasil, 1870-1930. São Paulo: Companhia das Letras, 1993.
SOUZA, Lincoln de. Preciosidades inestimáveis num museu de Sergipe. A Noite, Rio de Janeiro, 12 maio 1953. p. 29.

TRAVASSOS, Elizabeth. Resenha do livro Projeto e missão: o Movimento Folclórico Brasileiro (1947-1964). Mana, Rio de Janeiro, v. 4, n. 1, p. 165-188, abr. 1998. DOI: http://dx.doi.org/10.1590/ S0104-93131998000100015.

VILHENA, Luís Rodolfo. Projeto e missão: o Movimento Folclórico Brasileiro (1947-1964). Rio de Janeiro: Funarte: Fundação Getúlio Vargas, 1997. 